\title{
Internet Uses and Its Relation to Academic Achievement and Obesity among Nursing Students at Minia University
}

\author{
Nagat F Abolwafa ${ }^{1 *}$ and Hend E Mohammed ${ }^{2}$ \\ ${ }^{1}$ Lecturer of Pediatric Nursing, Faculty of Nursing, Minia University \\ ${ }^{2}$ Lecturer of Medical Surgical Nursing, Faculty of Nursing, Minia University
}

\begin{abstract}
Background: Computers and internet play a major role in our daily lives; this has brought about both the positive and the negative effect upon people, particularly upon youth and university students. Internet uses can pose a negative effect on academic achievement as well as body weight Aim: to assess the effect of internet uses on academic achievement and obesity among nursing students at Minia University.

Design: A Descriptive cross-sectional research design was used to conduct this study.

Setting: This study was conducted at Secondary school of nursing, Technical institute of nursing, 1st and $4^{\text {th }}$ year of Faculty of nursing, nursing students who registered for Master and Doctorate degree at Minia University.

Sample: A total sample of 500 nursing students was found eligible for participation.

Tools: A self-administered questionnaire was designed and includes personal demographic, questions about students internet uses and anthropometric measurements.

Results: This study showed significant increase in educational achievement and over obesity among adult nursing students than adolescences nursing students.

Conclusion: There was remarkable effect of uses of internet on body weight and academic achievement among nursing students at Minia University.

Recommendation: Develop program for students about the effect of uses internet on body weight and academic achievement of nursing students in the same study setting and adopted in other similar settings.
\end{abstract}

Keywords: Academic Achievement, Internet uses, Nursing Students, Obesity

\section{Introduction}

Internet is a main element of life, that can't be obsolete. A large community is uses internet for educational aim but regrettably, we have a large community including majority of youth and teenagers who using internet for only internet sites (Boyd, 2006).

According to Kuppuswamy and Shankar (2010), the internet websites conquest interest of the students and then refers it towards non-educational and unsuitable actions including useless chatting. Because of the statement above, we can say that internet sites could sorely influence the academic life and learning practice of the student. While on the other hand reviewed that the students are do conversation on several topics and socially connected with each other for sharing their daily learning experiences (Liccardi et al, 2007).

WHO stated that the problem of adolescent obesity is global. The prevalence of obesity in Thai adolescents has increased from $12.2 \%$ to $15.6 \%$ in 2010 to 2012. (WHO, 2012)

Most studies have mainly reported a positive association between screen-time activities and body mass index (BMI) in adolescence (Mitchell et al., 2013). The more adolescents would use the internet, the less they would have time and inclination to do their homework, sport and physical activity. Nevertheless, most of the studies were cross-sectional and, consequently, the direction of the association could not be plainly determined. Furthermore, several studies showed that a reverse association between physical activity and overweight could be the cause of internet and screen use, not its consequence (Fakhouri et al., 2013). Indeed, overweight adolescents seemed to practice less physical activity because of pain or embarrassment (Metcalf et al., 2011). The overweight and obesity are now increasing, essentially in developing counties. This can lead to increased burden of poor quality of life and health care. The important reasons behind the cause in these health problems include convenient or ready-to-eat meals, increasing consumption of fast foods, junk foods and sweets, soft drinks among adolescents and variations in the physical patterns of adolescents from playing at the domain to watching television, surfing the internet and playing computer games. The prevalence of childhood obesity is increasing around the world. The World Health Organization (WHO) has classified obesity as a universal epidemic. There are 155 million (1 in 10) childrens classified as overweight and about 30-45 million as obese in worldwide (Gabriela, 2007).

The internet is "the act of engagement" however internet is the tool used to communicate with mass audience. Social Media is the platform that using two way communication, give individuals the opportunity to 
interact; meaning, so as to anyone who has online accounts can share their opinions with other social media users (Hartshorn, 2010) and (Richards Richards, 2012).

The internet has been used in so many different ways over the years. Egypt is known to be one of the large users of social media, specifically Facebook. It predominates 25\% of the total MENA region, having nearly 11 million users, even though the penetration rate is only about $13 \%$. In the first 6 months of the year 2012, Egypt had an additional 1,608,420 users on Facebook, which is the highest number in the MENA region. Luke Richards stated that $46 \%$ of Egyptian social media users confirm that social media has major influence in empowering them to change their country (Curtis, 2013). According to Dr. Anthony Curtis, 2014, there is 255 million Twitter users and 1.28 billion Facebook users, in Arab world there is about 3.7 million of the Twitter users and 55 million of the Facebook users (Curtis, 2013).

\section{Research Questions}

1. Is there a relationship between the use the internet and obesity among nursing students?

2. Is there a relationship between the use the internet and academic achievement among nursing students?

\section{Methodology}

This descriptive cross-sectional study measured the relation of internet uses on academic achievement and obesity among nursing students at Minia University. Eligibility criteria included sample of students male or female Secondary school of nursing, Technical institute of nursing, 1st and $4^{\text {th }}$ year of Faculty of nursing, nursing students who registered for Master and Doctorate degree at Minia University who are agree to participate in this study. The number of student's nurses who were found eligible for participation was 500 nurses.

Data collection carried out in the period between November 2015 to January 2017.A permission to conduct the study was obtained from each selected institution administrator and the teaching staff prior to administration of the questionnaire. Participants' consent was obtained at the early stage of the study including the steps of ensuring confidentiality and anonymity. Students were informed by the researchers about the study aim. They were instructed on how to fill out the questionnaire completely and truthfully.

Each subject was weighed in kilogram $(\mathrm{kg})$ in indoor clothing without shoes. Standing height was measured without shoes.A pilot study was carried out on 50 nurses prior to data collection to assess the clarity of the study instruments.

\section{Instruments}

A self-administered questionnaire was designed to include the following elements:

1. Personal demographic data including; age, sex and type of study and end results in year of academic achievement.

2. Questions about students internet uses regarding the number of hours they use internet per day and for what they use internet, facilities methods to access use internet, eating habits with net uses. Anthropometric measurements include weight and height to measure body mass index (BMI) according to guidelines stated by the National Institutes of Health, weight status was classified into four categories for children (CDC) Growth charts $5^{\text {th }}$ and $95^{\text {th }}$ percentile include: obesity $\geq 95^{\text {th }}$, overweight $\geq 85^{\text {th }}$ and $\leq 95^{\text {th }}$, underweight $<$ $5^{\text {th }}$ and short stature $<5^{\text {th }}$ (WHO and CDC, 2013). And for adult: Underweight (BMI 18.5), normal weight (BMI between 18.5-24.9), overweight (BMI between 25-29.9), and obese (BMI $\geq 30)$ (WHO, 2004).

\section{Statistical Design}

Statistical analysis was performed using the Statistical Package for Social Sciences (Version 20.0, SPSS, Inc) software. Results were expressed as means \pm SD (standard deviation). A descriptive statistic were used, frequency and percentage, and parametric variables will be analyzed using students test, while chi-squared analysis was conducted for non-parametric variables. All reported $\mathrm{P}$ values were made on the basis of 2 -sided tests and compared to a significance level of $5 \%$. The differences were considered statistically significant at $\mathrm{P}<$ 0.05 .

VI. Results

Table (1): Characteristics of Study Sample $\mathrm{n}_{=} 500$

\begin{tabular}{|l|l|l|}
\hline Items & No & \% \\
\hline Age in years: & & \\
Adolescences & 125 & 25 \\
Middle adolescences (15-18) & 125 & 25 \\
Late adolescences (19-20) & 100 & \\
Adult & 100 & 20 \\
$22-25$ & 50 & 20 \\
$26-30$ & & 10 \\
$31-36$ & & \\
\hline
\end{tabular}




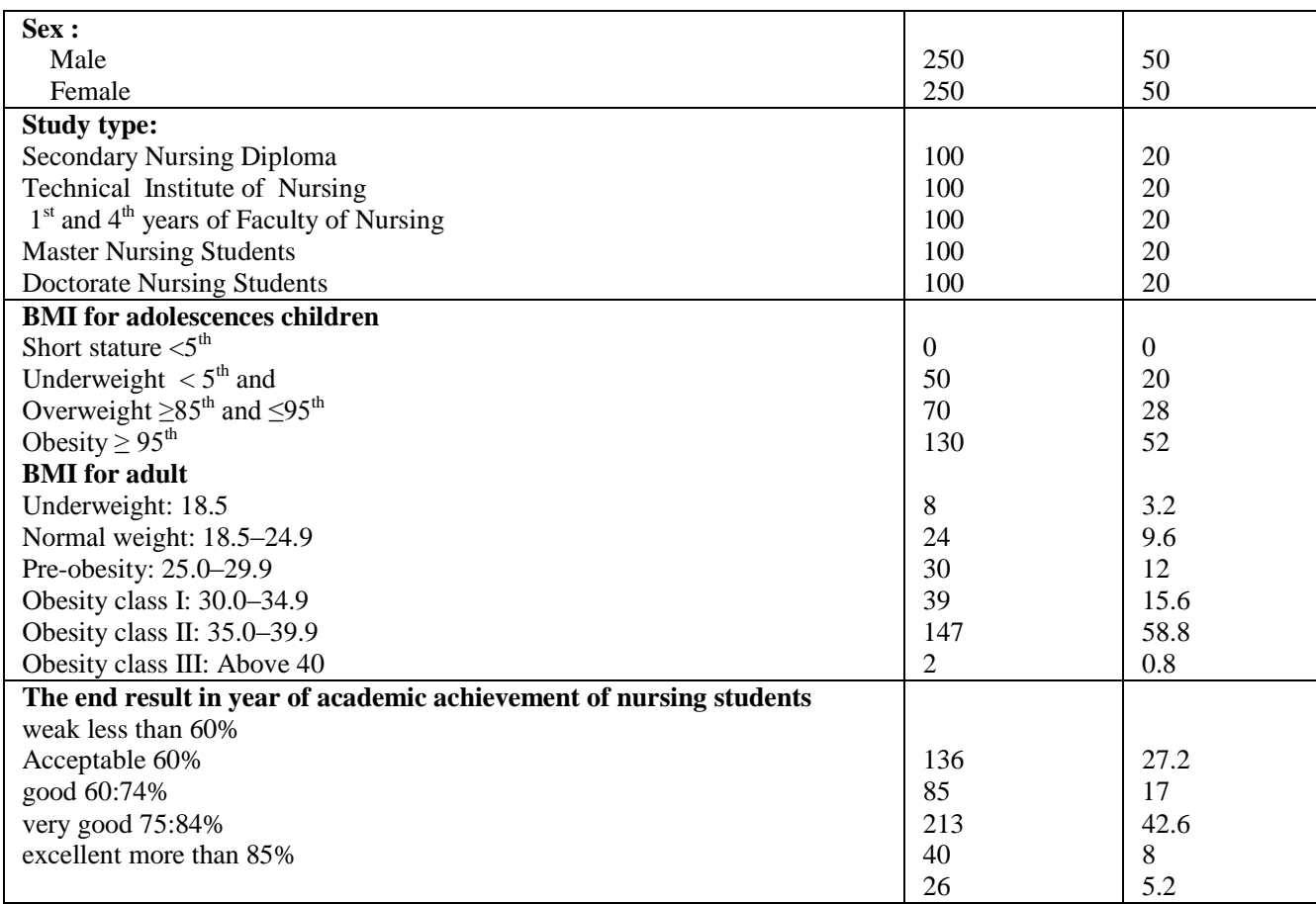

Table (1) illustrates the characteristics of the studied sample. It was found that, the minor number $(10 \%)$ of them was aged 31:36 years. As regards sex of the studied sample it was found that, half of them $(50 \%)$ were female and $(50 \%)$ were male. While the study type were equals $(20 \%)$ in Secondary Nursing Diploma, Technical Institute of Nursing, Faculty of Nursing, Master Nursing and Doctorate Nursing Students. As regards the body mass index (BMI) for adolescences children it was found (52\%) were obesity, while for adult it was found that $(58.8 \%)$ were obesity class II: $35.0-39.9$. While the end result in year of academic achievement. It indicates that numbers of nursing students $(42.6 \%)$ have good while excellent more than $85 \%(5.2 \%)$.

Table (2): Distribution of nursing students facilities methods to access use internet $\mathrm{n}=500$

\begin{tabular}{|l|l|l|}
\hline Items & No & \% \\
\hline types of communication used by the online network & 500 & 100 \\
Mobile & 30 & 6 \\
Computer & 300 & 60 \\
laptop & 10 & 2 \\
IPAD & 5 & 1 \\
Tablet & & \\
\hline How many media available to you to connect to the net? & 70 & 14 \\
One & 430 & 86 \\
More than one & & \\
\hline The total time you spend in the use of social networking & 20 & 4 \\
Less than 2 hours & 30 & 6 \\
2:4 hours & 200 & 40 \\
5:8 hours & 250 & 50 \\
More than 8 hours & & \\
\hline Does every person have a way to connect to the net? & 500 & 100 \\
Yes & 0 & 0 \\
No & & \\
\hline Is there a computer, lap, IPAD Internet-connected? & 392 & 78.4 \\
In bed room & 108 & 21.6 \\
\hline Outside bed room & & \\
\hline family put a reasonable but firm rules about the use of the net & 78 & 15.6 \\
Yes & 422 & 84.4 \\
\hline no & & \\
\hline What family is used in applying the rules on the use of social media? & 311 & 62.2 \\
Discussion and talk & 189 & 37.8 \\
\hline violence & & \\
\hline
\end{tabular}

Table (2) show that the distribution of nursing students facilities methods to access use interne. It was found that, $100 \%$ were used mobile in nursing students. $86 \%$ of nursing students have more than one media connected to the interne. As regards the nursing students total time spend in using internet, it was noticed that, 
the majority of them (50\%) were spend more than 8 hours. $100 \%$ of every person have a way to connect to the net. As regards the nursing students methods of internet connected to the internet in bed room (78.4\%) in nursing students. As regarding to the family of studied sample didn't put a reasonable but firm rules about the use of the net were (84.4\%) in nursing students. Regarding to what family is used in applying the rules on the use of internet to studied sample were discussion and talk were (62.2\%) in nursing students while (37.8\%) use violence.

Table (3): The relation between study type and body mass index (BMI) of adolescences nursing students $n=250$

\begin{tabular}{|c|c|c|c|c|c|c|c|}
\hline \multirow[t]{2}{*}{ Items } & \multicolumn{2}{|c|}{$\begin{array}{l}\text { Secondary } \\
\text { Nursing Diploma } \\
\mathrm{n}=100\end{array}$} & \multicolumn{2}{|c|}{$\begin{array}{l}\text { Technical } \\
\text { Institute of } \\
\text { Nursing } \\
\mathbf{n}=100\end{array}$} & \multicolumn{2}{|c|}{$\begin{array}{ll}\mathbf{1}^{\text {st }} \text { years } & \text { of } \\
\text { Faculty } & \text { of } \\
\text { Nursing } & \\
\mathbf{n = 5 0} & \\
\end{array}$} & \multirow[t]{2}{*}{ P. value } \\
\hline & No & $\%$ & No & $\%$ & No & $\%$ & \\
\hline BMI & \multirow[b]{2}{*}{0} & \multirow[b]{2}{*}{0} & \multirow[b]{2}{*}{0} & \multirow[b]{2}{*}{0} & \multirow[b]{2}{*}{0} & \multirow[b]{2}{*}{0} & \multirow{5}{*}{$\begin{array}{l}\mathrm{X} 2=0.45 \\
0.005^{*}\end{array}$} \\
\hline Short stature $<5^{\text {th }}$ & & & & & & & \\
\hline Underweight $<5^{\text {th }}$ & 15 & 15 & 30 & 30 & 5 & 10 & \\
\hline Overweight $\geq 85^{\text {th }}$ and $\leq 95^{\text {th }}$ & 35 & 35 & 25 & 25 & 10 & 20 & \\
\hline Obesity $\geq 95^{\text {th }}$ & 50 & 50 & 45 & 45 & 35 & 70 & \\
\hline
\end{tabular}

*= Significant

Table (3) shows the relation between the study type and body mass index (BMI) of adolescences nursing students. It indicates $35 \%$ of secondary nursing diploma students body mass index (BMI) were overweight $\geq 85^{\text {th }}$ and $\leq 95^{\text {th }}$ and $50 \%$ of nursing students body mass index (BMI) and obesity $\geq 95^{\text {th }}$. While for technical institute of nursing body mass index (BMI) were $30 \%$ overweight $\geq 85^{\text {th }}$ and $\leq 95^{\text {th }}$. As for Obesity $\geq$ $95^{\text {th }}$ were increased between $1^{\text {st }}$ years of faculty of nursing students $(70 \%)$. However, the adolescences nursing students relations to the body mass index (BMI) were reached statistically significant difference (P.0.005).

Table (4): The relation between study type and body mass index (BMI) of adult nursing students $n=250$

\begin{tabular}{|c|c|c|c|c|c|c|c|}
\hline \multirow[t]{2}{*}{ Items } & \multicolumn{2}{|c|}{$\begin{array}{ll}4^{\text {th }} \text { year } & \text { of } \\
\text { Faculty } & \text { of } \\
\text { Nursing } & \\
n=50 & \end{array}$} & \multicolumn{2}{|c|}{$\begin{array}{l}\text { Master } \\
\text { Nursing } \\
\text { Students } \\
\mathbf{n}=\mathbf{1 0 0}\end{array}$} & \multicolumn{2}{|c|}{$\begin{array}{l}\text { Doctorate } \\
\text { Nursing } \\
\text { Students } \\
\mathbf{n}=100\end{array}$} & \multirow[t]{2}{*}{ P. value } \\
\hline & No & $\%$ & No & $\%$ & No & $\%$ & \\
\hline$\overline{\text { BMI }}$ & \multirow[b]{2}{*}{0} & \multirow[b]{2}{*}{0} & \multirow[b]{2}{*}{3} & \multirow[b]{2}{*}{3} & \multirow[b]{2}{*}{5} & \multirow[b]{2}{*}{5} & \multirow{7}{*}{$\begin{array}{l}X 2=0.55 \\
0.000 *\end{array}$} \\
\hline Underweight: 18.5 & & & & & & & \\
\hline Normal weight: $18.5-24.9$ & 5 & 10 & 15 & 15 & 4 & 4 & \\
\hline Pre-obesity: $25.0-29.9$ & 10 & 20 & 20 & 20 & 0 & 0 & \\
\hline Obesity class I: $30.0-34.9$ & 25 & 50 & 3 & 3 & 11 & 11 & \\
\hline Obesity class II: $35.0-39.9$ & 15 & 30 & 52 & 52 & 80 & 80 & \\
\hline Obesity class III: Above 40 & 0 & 0 & 2 & 2 & 0 & 0 & \\
\hline
\end{tabular}

$*=$ Significant

Table (4) shows the relation between the study type and body mass index (BMI) of adult nursing students. It indicates 3\% of master nursing students body mass index (BMI) were underweight: 18.5. While the majority of nursing students body mass index (BMI) were obesity class II: 35.0-39.9 were increased between Doctorate nursing students $(80 \%)$. However, the study type relations to the body mass index (BMI) were reached statistically significant difference (P.0.000).

Table (5): The relation between study type and the end result in year of academic achievement $n=500$

\begin{tabular}{|c|c|c|c|c|c|c|c|c|c|c|c|}
\hline \multirow[t]{2}{*}{ Items } & \multicolumn{2}{|c|}{$\begin{array}{l}\text { Secondary } \\
\text { Nursing } \\
\text { Diploma } \\
\text { n=100 }\end{array}$} & \multicolumn{2}{|c|}{$\begin{array}{l}\text { Technical } \\
\text { Institute of } \\
\text { Nursing } \\
n=100\end{array}$} & \multicolumn{2}{|c|}{$\begin{array}{l}\text { Faculty of } \\
\text { Nursing } \\
\mathbf{n}=\mathbf{1 0 0}\end{array}$} & \multicolumn{2}{|c|}{$\begin{array}{l}\text { Master Nursing } \\
\text { Students } \\
\mathbf{n}=100\end{array}$} & \multicolumn{2}{|c|}{$\begin{array}{l}\text { Doctorate } \\
\text { Nursing } \\
\text { Students } \\
\text { n=100 }\end{array}$} & \multirow[t]{2}{*}{ P. value } \\
\hline & No & $\%$ & No & $\%$ & No & $\%$ & No & $\%$ & No & $\%$ & \\
\hline $\begin{array}{l}\text { The end result in year of } \\
\text { academic achievement }\end{array}$ & 33 & 33 & 18 & 18 & 17 & 17 & 13 & 13 & 20 & 20 & $\begin{array}{l}\mathbf{X}^{2}=0.66 \\
0.000^{*}\end{array}$ \\
\hline weak less than $60 \%$ & & & & & & & & & & & \\
\hline Acceptable $60 \%$ & 14 & 14 & 28 & 28 & 35 & 35 & 20 & 20 & 25 & 25 & \\
\hline Good 60:74\% & 23 & 23 & 27 & 27 & 13 & 13 & 40 & 40 & 27 & 27 & \\
\hline Very good 75:84\% & 30 & 30 & 24 & 24 & 17 & 17 & 14 & 14 & 18 & 18 & \\
\hline Excellent more than $85 \%$ & 0 & 0 & 3 & 3 & 18 & 18 & 13 & 13 & 10 & 10 & \\
\hline
\end{tabular}

$*=$ Significant 
Table (5) illustrates the relation between the study type and the end result in year of academic achievement. It indicates that nursing students have scores weak 33\% among secondary nursing diploma, acceptable scores $35 \%$ who have faculty of nursing students, good scores $40 \%$ who have master nursing students, very good scores $30 \%$ who have secondary nursing diploma and excellent scores $18 \%$ who have faculty of nursing students. These differences were reached statistically significant difference (P.0.000).

Table (6): The relation between total time of use internet and body mass index (BMI) of adolescences nursing students $n=250$

\begin{tabular}{|c|c|c|c|c|c|c|c|c|c|}
\hline \multirow[t]{2}{*}{ Items } & \multicolumn{2}{|c|}{$\begin{array}{l}\text { Less than } \\
2 \text { hours }\end{array}$} & \multicolumn{2}{|c|}{$\begin{array}{l}\text { From } \\
2: 4 \text { hours }\end{array}$} & \multicolumn{2}{|c|}{$\begin{array}{l}\text { From } \\
\text { 5:8 hours }\end{array}$} & \multicolumn{2}{|c|}{$\begin{array}{l}\text { More Than } \\
8 \text { hours }\end{array}$} & \multirow[t]{2}{*}{ P. value } \\
\hline & No & $\%$ & No & $\%$ & No & $\%$ & No & $\%$ & \\
\hline BMI & \multirow[b]{2}{*}{0} & \multirow[b]{2}{*}{0} & \multirow[b]{2}{*}{0} & \multirow[b]{2}{*}{0} & \multirow[b]{2}{*}{0} & \multirow[b]{2}{*}{0} & \multirow[b]{2}{*}{0} & \multirow[b]{2}{*}{0} & \multirow{5}{*}{$\begin{array}{l}\mathrm{X} 2=0.60 \\
0.003^{*}\end{array}$} \\
\hline Short stature $<5^{\text {th }}$ & & & & & & & & & \\
\hline Underweight $<5^{\text {th }}$ & 0 & 0 & 3 & 6 & 17 & 34 & 30 & 60 & \\
\hline Overweight $\geq 85$ th and $\leq 95^{\text {th }}$ & 0 & 0 & 5 & 7.2 & 11 & 15.7 & 54 & 77.1 & \\
\hline Obesity $\geq 95^{\text {th }}$ & 0 & 0 & 5 & 3.8 & 8 & 6.2 & 117 & 90 & \\
\hline
\end{tabular}

*= Significant

Table (6) illustrates the relation between the total time of internet use and body mass index (BMI) of adolescences nursing students. It indicates the majority number of nursing students body mass index (BMI) were obesity $\geq 95^{\text {th }}$ were increased between nursing students spend time in using internet more than 8 hours $(90 \%)$. However, the body mass index (BMI) relation to the total time spend in using internet were reached statistically significant difference (P.0.003).

Table (7): The relation between total time of use internet and body mass index (BMI) of adult nursing students

\begin{tabular}{|c|c|c|c|c|c|c|c|c|c|}
\hline & & & & $=250$ & & & & & \\
\hline \multirow[t]{2}{*}{ Items } & \multicolumn{2}{|c|}{$\begin{array}{l}\text { Less than } \\
2 \text { hours }\end{array}$} & \multicolumn{2}{|c|}{$\begin{array}{l}\text { From } \\
\text { 2:4 hours }\end{array}$} & \multicolumn{2}{|c|}{$\begin{array}{l}\text { From } \\
\text { 5:8 hours }\end{array}$} & \multicolumn{2}{|c|}{$\begin{array}{l}\text { More Than } \\
8 \text { hours }\end{array}$} & \multirow[t]{2}{*}{ P. value } \\
\hline & No & $\%$ & No & $\%$ & No & $\%$ & No & $\%$ & \\
\hline BMI & \multirow[b]{2}{*}{0} & \multirow[b]{2}{*}{0} & \multirow[b]{2}{*}{3} & \multirow[b]{2}{*}{37.5} & \multirow[b]{2}{*}{0} & \multirow[b]{2}{*}{0} & \multirow[b]{2}{*}{5} & \multirow[b]{2}{*}{62.5} & \multirow{7}{*}{$\begin{array}{l}\mathrm{X} 2=0.72 \\
0.002 *\end{array}$} \\
\hline Underweight: 18.5 & & & & & & & & & \\
\hline Normal weight: $18.5-24.9$ & 2 & 8.3 & 0 & 0 & 10 & 41.7 & 12 & 50 & \\
\hline Pre-obesity: $25.0-29.9$ & 0 & 0 & 5 & 16.6 & 7 & 23.4 & 18 & 60 & \\
\hline Obesity class I: $30.0-34.9$ & 0 & 0 & 0 & 0 & 19 & 48.7 & 20 & 51.3 & \\
\hline Obesity class II: $35.0-39.9$ & 0 & 0 & 0 & 0 & 7 & 4.7 & 140 & 95.3 & \\
\hline Obesity class III: Above 40 & & & & & & & 2 & 2 & \\
\hline
\end{tabular}

*= Significant

Table (7) illustrate the relation between the total time of internet use by adult nursing students and body mass index (BMI). It indicates the majority number of nursing students body mass index (BMI) were obesity class II: $35.0-39.9$ were increased between nursing students spend time in using internet more than 8 hours (95.3\%). However, the body mass index (BMI) relation to the total time spend in using internet were reached statistically significant difference (P.0.002).

Table (8): The relation between nursing students total time of use internet and the end result in year of academic achievement $\mathrm{n}=500$

\begin{tabular}{|c|c|c|c|c|c|c|c|c|c|}
\hline \multirow[t]{2}{*}{ Items } & \multicolumn{2}{|c|}{$\begin{array}{l}\text { Less Than } \\
2 \text { hours }\end{array}$} & \multicolumn{2}{|c|}{$\begin{array}{l}\text { From } \\
\text { 2:4 hours }\end{array}$} & \multicolumn{2}{|c|}{$\begin{array}{l}\text { From } \\
\text { 5:8 hours }\end{array}$} & \multicolumn{2}{|c|}{$\begin{array}{l}\text { More than } \\
8 \text { hours }\end{array}$} & \multirow[t]{2}{*}{ P. value } \\
\hline & No & $\%$ & No & $\%$ & No & $\%$ & No & $\%$ & \\
\hline $\begin{array}{l}\text { The end result in year of } \\
\text { academic achievement }\end{array}$ & \multirow[b]{2}{*}{2} & \multirow[b]{2}{*}{1.6} & \multirow[b]{2}{*}{2} & \multirow[b]{2}{*}{1.6} & \multirow[b]{2}{*}{20} & \multirow[b]{2}{*}{14.5} & \multirow[b]{2}{*}{112} & \multirow[b]{2}{*}{82.3} & $\begin{array}{l}\mathbf{X}^{2}=0.76 \\
0.000^{*}\end{array}$ \\
\hline weak less than $60 \%$ & & & & & & & & & \\
\hline Acceptable $60 \%$ & 3 & 3.5 & 2 & 2.3 & 80 & 94.2 & 0 & 0 & \\
\hline Good 60:74\% & 10 & 4.6 & 10 & 4.6 & 13 & 6.3 & 180 & 84.5 & \\
\hline Very good 75:84\% & 0 & 0 & 0 & 0 & 10 & 20 & 40 & 80 & \\
\hline Excellent more than $85 \%$ & 0 & 0 & 0 & 0 & 26 & 100 & 0 & 0 & \\
\hline
\end{tabular}

*= Significant

Table (8) illustrates the relation between the total time of social media used by nursing students and the end result in year of academic achievement. It indicates that nursing students have scores weak $82.3 \%$ use internet more than 8 hours, acceptable scores $94.2 \%$ who use internet from $5: 8$ hours, good scores $84.5 \%$ who 
use internet more than 8 hours, very good scores $80 \%$ who use internet more than 8 hours and excellent scores $100 \%$ who use internet from 5:8 hour. These differences were reached statistically significant difference (P.0.000).

Table (9): Distribution of nursing students unhealthy behavior related to uses of internet $n=500$

\begin{tabular}{|l|l|l|}
\hline Items & \multicolumn{2}{l|}{ Nursing students } \\
\cline { 2 - 3 } & No & \% \\
\hline $\begin{array}{l}\text { You are the type who eats while watching or working on the computer or } \\
\text { other methods. }\end{array}$ & & \\
Yes & 359 & 71.8 \\
No & 141 & 28.2 \\
\hline $\begin{array}{l}\text { What is the number of meals we eat a day? } \\
\text { Less than 3 meal per day }\end{array}$ & 85 & 17 \\
3 meal per day & 15 & 3 \\
More than 3 meal per day & 400 & 80 \\
\hline Does our presence in the era of speed and use the net increase of obesity? & & \\
Yes & 464 & 92.8 \\
No & 36 & 7.2 \\
\hline $\begin{array}{l}\text { Do you prefer to eat fast food? } \\
\text { Yes }\end{array}$ & 479 & 95.8 \\
No & 21 & 4.2 \\
\hline $\begin{array}{l}\text { Drinks favored by type? } \\
\text { normal juices } \\
\text { canned juices }\end{array}$ Carbonated drinks & 59 & 11.8 \\
all above & 90 & 18 \\
\hline Do you practice walking or any other sport? & 100 & 20 \\
yes, from 1: 3 days per week & 251 & 50.2 \\
\hline yes, from 3:6 days per week & & \\
every day in week & 80 & 16 \\
not practice & 9 & 1.8 \\
\hline Have you ever participated diet regime before it? & 0 & 0 \\
Yes & 411 & 82.2 \\
\hline No & & \\
\hline
\end{tabular}

Table (9): indicated that the distribution of nursing students unhealthy behavior related to exaggerate use of internet. It was found that, $(80 \%)$ were eating more than 3 meals per day and (17\%) eat less than 3 meal per day of nursing students. It was found that, (92.8\%) of nursing students were consider that our presence in the era of speed and use the net increase of obesity. It was notice that $(95.8 \%)$ were preferred to eat fast food of nursing students. It was notice that nursing students who didn't' practice sport $(82.2 \%)$ of nursing students.

Table (10): The correlation between the total time of nursing students spend in using internet and end result in year of academic achievement and body mass index (BMI) $n=500$

\begin{tabular}{|l|l|l|}
\hline \multirow{2}{*}{ Items } & \multicolumn{2}{|l|}{ The total time of nursing students spend in using internet } \\
\cline { 2 - 4 } & Correlation Coefficient $(\mathbf{r})$ & P. value \\
\hline BMI & 0.95 & $0.001^{*}$ \\
\hline The end result of education & 0.85 & $0.001^{*}$ \\
\hline
\end{tabular}

$$
*=\text { Significant }
$$

Table (10) shows the correlation between the total time of nursing students spend in using internet and the end result in year of academic achievement and body mass index (BMI). It is evident that the highest strong positive statistical significant correlation was found between the total time of nursing students spend in the using internet and body mass index (BMI) $(\mathrm{r}=0.95)$. The lowest strong positive statistical significant correlation was found between The total time of nursing students spend in the using internet and the end result in year of academic achievement $(\mathrm{r}=0.85)$.

\section{Discussion}

This study aims to identify the effect of internet uses on academic achievement and obesity among nursing students at Minia University.The current study revealed that, half of nursing students were female this result supported with (Vahid et al 2013). Although the number of men entering nursing profession is on the increase, there has not been a considerable increase in the percentage of men in nursing

The study findings, half of them were female. These findings are in line with (Abdel Kader et al, 2012) who reported the mean age for the subjects were $22.36+0.89$. The majority $(84.29 \%)$ of them were females. 
The current study revealed that, $100 \%$ were used mobile in nursing students. Two third of nursing students connect with internet by several mean such as phone, computer, lab top and tablet. This finding support with (Kimchhoy and Javier, 2015) who found that almost a third of Cambodians have access to the internet and facebook and most of the people in this age have their own facebook accounts. Smart phones are by away the most common means of accessing facebook; only 3\% of users access the social media site just through computers; however $80 \%$ access it exclusively through phones

The availability of high speed internet broadband link with massive using of desktop computers, laptops, e-readers, smart phones and tablets enable millions of undergraduates to actively engage in social networking, blogging, text messaging, content sharing and online learning (Kanelechi et al , 2014).

The finding of this study were reported two third of studied sample family didn't put a reasonable but firm rules about the use of the net and this result in the same line with (Madden et al. 2012) who state that two thirds of American parents of teens using a social networking site, mostly Facebook, and $80 \%$ of them have friended their child.In additional (Hart Research Associates, 2011) state that parents whose children access the Internet using a smartphone or handheld device ( $48 \%$ of total sample) find it more difficult to control their child's online activity on these devices. (33\%) of these parents find it difficult to supervise their child's usage on a smartphone or handheld device.

The present study indicates $35 \%$ of secondary nursing diploma students body mass index (BMI) were overweight $\geq 85^{\text {th }}$ and $\leq 95^{\text {th }}$ and $50 \%$ of nursing students body mass index (BMI) and obesity $\geq 95^{\text {th }}$. While for technical institute of nursing body mass index (BMI) was $30 \%$ overweight $\geq 85^{\text {th }}$ and $\leq 95^{\text {th }}$. As for Obesity $\geq 95^{\text {th }}$ were increased between $1^{\text {st }}$ years of faculty of nursing students $(70 \%)$ This finding support with (Laurson et al., 2014) his concern is very often associated with sedentariness such as screen-time activities and use the net. This kind of occupations could decrease physical activity and cause sleep disturbances and meals, which should affect the health and weight of adolescents.

Social norm influences US children's BMI growth. High obesity prevalence will lead to a continuous rise in children's BMI due to increased socially acceptable mean BMI. Interventions promoting healthy body image and desirable socially acceptable BMI could be implemented to control childhood obesity epidemic (Hugues et al., 2012).

The current study revealed that, the majority of nursing students body mass index (BMI) were obesity class II: 35.0-39.9 were increased between Doctorate nursing students $(80 \%)$. This finding support with (Nicholas, 2007) who found the prevalence of obesity has increased from $23 \%$ to $31 \%$ over the recent past in the United States and 66\% of adults are overweight. Proposed explanations for the obesity epidemic include societal changes that promote both food consumption and inactivity the fact which the increase in obesity during this period can't be explained by genetics and has existed among all socioeconomic groups. Provides support for a broad set of social and environmental explanations. Since diverse phenomena may spread within social networks, we conducted a study to determine whether obesity might also spread from person to person, possibly contributing to the epidemic and how the spread might occur.

As regard unhealthy eating behaviour the study represent that, nursing student were preferred eating fast food and this result at the same line with (Hugues et al., 2012) who reported that unhealthy eating behavior and excess body weight have been related to sedentary behavior, particularly screen time, in adolescents while, little is known about their associations with the use of social networking sites (SNS). We investigated the associations between time spent using SNS and unhealthy eating behaviors (including breakfast skipping, energy drinks and consumption of sugar-sweetened beverages (SSB)) and body weight in adolescents there was no evidence of a significant association between use of SNS and BMI before or after adjusting for all the covariates and unhealthy eating behaviors (Hugues et al., 2012).

According to the bed habits that have relation with nursing student academic achievement the current result found that the majority nursing students have scores weak and they use internet more than 8 hours $\mathrm{s}$ in study this result support with (Noah and Charity, 2013) who found that nursing student's ability to concentrate on the task at hand is significantly decreased by distractions brought about by Face book, Twitter and YouTube. Higher education administrators, faculty and staff have an opportunity to help students using facebook in ways that are useful to their engagement and by extension to their overall academic experience. Given that facebook continues to be popular among college students and that universities are interested in engaging and retaining students, it is significant for those working in higher education to familiarize themselves with facebook, other such technologies, design and support interventions that meet students where they are in order to help them get to where they are going (Reynol Junco, 2011).

The current study revealed that, highly statically significant between time spend in social media and student academic achievement in this result at the same line with (Junco, 2012) who found that time spent on facebook and checking facebook are shown to negatively impact academic performance.

Result from the study shows that social network sites such as facebook affects the scholars of Asia Pacific University (Aida et al. 2014). 
There is a fair amount of professional and popular interest in the effects of social media on college student development and success (Abramson, 2011; Kamenetz, 2011).

The most popular social media website for college students is Facebook, and research shows that anywhere between 85 and 99\% of college students use Facebook (Hargittai, 2008; Jones \& Fox, 2009; Matney \& Borland, 2009).

Educause Center for Applied Research (ECAR) from a sample of 36,950 students from 126 U.S. universities and one Canadian university, showed that of the $90 \%$ of students who use social networking websites, 97\% said they used Facebook. This 97\% reported actively engaging on the site daily (Smith \& Caruso, 2010).

While the percentage of students who use social media and Facebook is high, it is important to acknowledge that there are persistent differences along gender, racial, and socioeconomic lines in technology adoption and use, often referred to as the digital divide (Junco, et al, 2010).

There was a significant negative relationship between frequency of engaging in Facebook chat and time spent preparing for class. A study by (Junco and Cotton, 2010) found that students who spent more time chatting online reported more academic impairment. While academic impairment was not evaluated in the current study, the negative relationship between engaging in Facebook chat and time spent preparing for class suggests that there is something about the process of online chatting that detracts from schoolwork; a topic important to explore in future research.

Both time spent on Facebook and time spent engaged in certain Facebook activities can be positively predictive, negatively predictive, or positively and negatively predictive of engagement, depending on the outcome variable. For example, time spent on Facebook is positively predictive of time spent in co-curricular activities while playing games on Facebook is negatively predictive (Junco and Cotton, 2012).

\section{Conclusion}

The findings of this study revealed that negative impact of uses of the internet on adolescences and adult nursing student on obesity and academic achievement.

\section{Recommendations}

The family member place rule about uses of the internet to minimize hazard on health and academic development, based on these results it is recommended to initiate national programs directed to adolescences and adult nursing student to provide them information about the proper internet use to avoid its negative impacts on obesity; and consequently on their academic achievement.

\section{References}

[1] Abdel Kader AM1. Mohamed EA. and Abood SA. (2012). Perception of Nurse Interns about Clinical Assignment Preparation Requirements Journal of American Science. 8(12): PP: 676. http://www.jofamericanscience.org

[2] Abramson L. (2011). Can social networking keep students in school? NPR: Morning Edition. http://www.npr.org/2011/02/09/

[3] Aida A. Behrang S. Behrooz G. (2014). A Study on the Negative Effects of Social Networking Sites Such as Facebook among Asia Pacific University Scholars in Malaysia International Journal of Business and Social Science. 5(10): PP: 133:145.

[4] Boyd D. (2006). Friends, fraudsters, and My Space Top 8: Writing community into being on social network sites. First Monday. 11(12).

[5] Curtis A. (2013): The Brief History of Social Media. The Brief History of Social Media.

[6] Fakhouri TI, Hughes JP, Brody DJ, Kit BK, Ogden CL. (2013). PHysical activity and screen-time viewing among elementary school-aged children in the united states from 2009 to 2010. JAMA Pediatr; 167: 223-229.

[7] Gabriela V. Sue D. David RJ. Karri S. (2007). Comparison of Body Mass Index, Waist Circumference and Waist/Hip Ratio in Predicting Incident Diabetes: A Meta-Analysis 7.

[8] Hargittai E. (2008). The digital reproduction of inequality. In D. Grusky (Ed.), Social stratification: PP: 936-944

[9] Hart Research Associates (2011): A Survey of Awareness, Attitudes, and Use of Online Parental Controls Findings from a National Survey Among Parents.

[10] Hartshorn S. (2010). 5 Differences between Social Media and Social Networking. Social Media Today.

[11] Hugues SK. Jean PC. and Hayley AH. (2015). Associations between the use of social networking sites and unhealthy eating behaviours and excess body weight in adolescents British Journal of Nutrition. 114(11): PP: 1941-1947 DOI: https: //doi.org /10.1017/S0007114515003566 Published online: 24 September 2015

[12] Jones S. \& Fox S. (2009). Data memo. Washington, DC: Pew Internet and American Life Project.

[13] Junco R. \& Cotten SR. (2010). Perceived academic effects of instant messaging use. Computers \& Education: PP: 56, $370-378$.

[14] Junco R. \& Cotton S. (2012). The relationship between multitasking and academic performance. Computers \& Education. 59(4): PP: $1-10$.

[15] Junco R. Heiberger G. \& Loken E. (2010). The effect of Twitter on college student engagement and grades. Journal of Computer Assisted Learning. doi:10.1111/j.1365- 2729.2010.00387.x

[16] Junco R. Heiberger G. \& Loken E. (2010). The effect of Twitter on college student engagement and grades. Journal of Computer Assisted Learning. doi:10.1111/j.1365- 2729.2010.00387.x

[17] Kamenetz A. (2011). Gates Foundation bets on Facebook app to help kids graduate. Fast Company. http://www.fastcompany

[18] Kanelechi CK. Nwangwa1, Ebun Y. (2012). Tope Omotere, Undergraduates and Their Use of Social Media: Assessing Influence on Research Skills Universal Journal of Educational Research. 2(6): PP: 446-453. 2014 http://www.hrpub.org DOI: 10.13189/ ujer.2014.020602 
[19] Kimchhoy P and Javier S. (2015).Mobile Phones and Internet in Cambodia. Open Institute, Development Innovations and the Asia Foundation. PP: 1:32

[20] Kuppuswamy S \& Narayan P. (2010). The Impact of Social Networking Websites on the Education of Youth. International Journal of Virtual Communities and Social Networking (IJVCSN). 2(1): PP: 67-79.

[21] Laurson KR, Eisenmann JC, Welk GJ, Wickel EE, Gentile DA, Walsh DA (2014). Combined influence of physical activity and screen time recommendations on childhood overweight. J Pediatr 2008; 153: 209-214.

[22] Liccardi I. Ounnas A. Pau R. Massey E. Kinnunen P. Lewthwaite S. Midy A. \& Sakar C. (2007). The role of social networks in students' learning experiences. ACM SIGCSE Bull. 39(4): PP: 224-237.

[23] Madden MC. Gasser U. Lenhart A. Duggan M. (2012). Parents, Teens, and Online Privacy. Pew Internet and American Life Project. vember 2015

[24] Matney M. \& Borland K. (2009). Facebook, blogs, tweets: how staff and units can use social networking to enhance student learning, Presentation at the annual meeting of the National Association for Student Personnel Administrators, Seattle, WA.

[25] Metcalf BS, Hosking J, Jeffery AN, Voss LD, Henley W, Wilkin TJ. (2011) Fatness leads to inactivity, but inactivity does not lead to fatness: a longitudinal study in children (EarlyBird 45). Arch Dis Child; 96: 942-947.

[26] Mitchell JA, Rodriguez D, Schmitz KH, Audrain-McGovern J. (2013) Greater screen time is associated with adolescent obesity: a longitudinal study of the BMI distribution from Ages 14 to 18. Obesity; 21: 572-575.

[27] Nicholas A. Christakis M.D. and James H. Fowler. (2007). The Spread of Obesity in a Large Social Network over 32 Years. N Engl J Med. 6(26): PP: 357:370-379. DOI: 10.1056/NEJMsa066082 The new England journal of medical

[28] Noah ED. Charity EM. (2013). effect of social media on the use of academic library by undergraduate students in tertiary institutions: a case study of kogi state university, anyigba. journal nurs midwifery stud. 2(4): PP: 49-56.

[29] Reynol J. (2011). The relationship between frequency of Facebook use, participation in Facebook activities, and student engagement Computers \& Education journal 58. PP: 162-171.

[30] Richards Richards L. (2012). Stats Social media growth and impact across the Middle East.

[31] Smith SD. \& Caruso JB. (2010). Research Study. ECAR study of undergraduate students and information technology. .http:// www. educause. edu/ Resources/ ECAR Study ofUndergraduateStuden/217333.

[32] Vahid Z. Leila V. Reza N. Morteza M. and Arman A. (2015). Factors Influencing Men Entering the Nursing Profession, and Understanding the Challenges Faced by Them: Iranian and Developed Countries' Perspectives. 20(2): PP: $167-172$.

[33] WHO (2004). Expert consultation. Appropriate body-mass index for Asian populations and its implications for policy and intervention strategies. PP: 157-163.

[34] WHO (2012). Geneva (GE). Global strategy on diet, physical activity and health.

[35] WHO (2013). National Center for Chronic Disease Prevention and Health Promotion Division of Nutrition, Physical Activity, \& Obesity. Use and Interpretation of the WHO and CDC Growth Charts for Children from Birth to 20 Years in the United States The WHO and CDC growth charts http://www.cdc.gov/growthcharts/who_charts.htm and http://www. cdc.gov/ growthcharts/clinical_charts.htm 